\title{
Waste Encapsulation and Storage Facility Waste Analysis Plan
}

Prepared for the U.S. Department of Energy

Assistant Secretary for Environmental Management

Project Hanford Management Contractor for the

U.S. Department of Energy under Contract DE-AC06-96RL13200

Fluor Hanford

P.o. Box 1000

Richland, Washington 


\section{INFORMATION CLEARANCE FORM}

\begin{tabular}{|c|c|c|}
\hline \multicolumn{2}{|c|}{ A. Information Category } & B. Document Number $4 / N F=7342$ \\
\hline $\begin{array}{l}\square \text { Abstract } \\
\square \text { Summary } \\
\square \text { Visual Aid } \\
\square \text { Full Paper }\end{array}$ & $\begin{array}{l}\square \text { Journal Article } \\
\square \text { Internet } \\
\square \text { Software } \\
\square \text { Report }\end{array}$ & 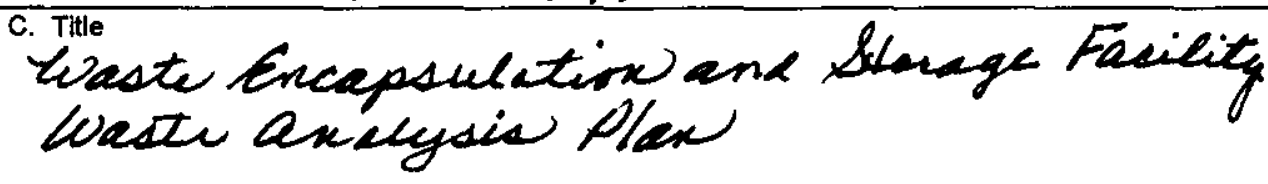 \\
\hline & & D. Internet Address \\
\hline
\end{tabular}

E. Required Information

1. Is document potentially classified? QNo OYes (MANDATORY)

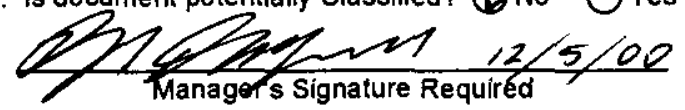

If Yes Dro Ores classified ADC Signature Required

2. Internal Review Required? if Yes, Document Signatures Below

Qro OYes

Counsel

Program

3. References in the Information are Applied Technology (1) OYo Export Controlled Information Dno Ores
4. Does Information Contain the Following: (MANDATORY)

a. New or Novel (Patentable) Subject Matter? D If "Yes", Disclosure No.:

b. Information Received in Confidence, Such as Proprietary and/or Inventions? (DNo OYes If "Yes", Affix Appropriate Legends/Notices.

c. Copyrights? QNo OYes If "Yes", Attach Permission.

d. Trademarks? $O$ No QPes "Yes", Identify in Document.

5. Is information requiring submission to OSTI? (D) No $O$ Yes If Yes $U C$ -

6. Release Level? (D) Public $\bigcirc$ Limited

7. Charge code__ $8159-19$

F. Complete for a Journal Article

1. Titie of Journal

G. Complete for a Presentation

1. Title for Conference or Meeting

2. Group Sponsoring

3. Date of Conference

5. Will Information be Published in Proceedings? $\bigcirc$ No $\bigcirc$ Yes $\quad$ 6. Will Material be handed Out? $\bigcirc$ No $\bigcirc$ Yes H. Author/Requestor Responsible Manager

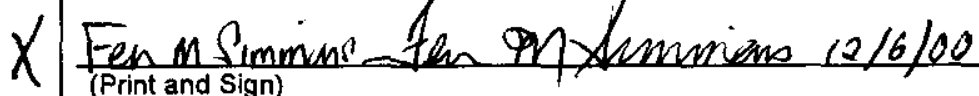

$x$

I. Reviewers

General Counsel

Office of External Affairs

DOE-RL

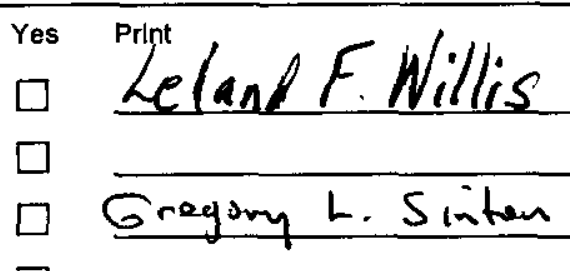

Other

$\square$

X Erian Pigntialat

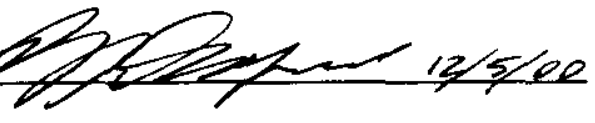

Signati.e

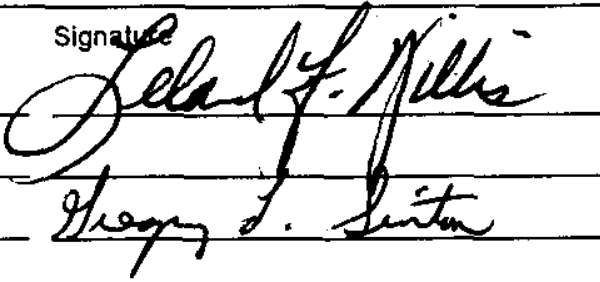

Public Y/N (If $N$, complete J)

Other

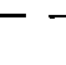

J. If Information Includes Sensitive information and is not to be released to the Public indicate category below.

$\square$ Applied Technology $\square$ Protected CRADA

$\square$ Personal/Private

$\square$ Export Controlled

$\square$ Proprietary

$\square$ Procurement-Sensitive

$\square$ Business-Sensitive

$\square$ Patentable

$\square$ Predecisional

$\square$ Other (Specify)

$\square$ UCNI

K. If Additional Comments, Please Attach Separate Sheet 
HNF-7342

Revision 0

\section{Waste Encapsulation and Storage Facility Waste Analysis Plan}

Date Published

December 2000

Prepared for the U.S. Department of Energy

Assistant Secretary for Environmental Management

Project Hanford Management Contractor for the

U.S. Department of Energy under Contract DE-AC06-96RL13200

Fluor Hanford

P.O. Box 1000

Richland, Washington

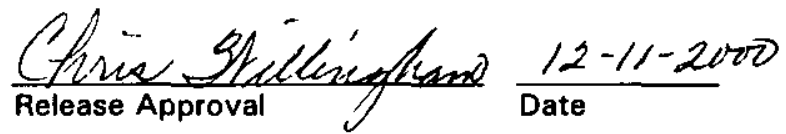




\section{LEGAL DISCLAIMER}

This report was prepared as an account of work sponsored by an agency of the United States Government. Neither the

United States Government nor any agency thereof, nor any of their employees, nor any of their contractors, subcontractors or their employees, makes any warranty, express or implied, or assumes any legal liability or responsibility for the accuracy, completeness, or any third party's use or the results of such use of any information, apparatus, product, or process disclosed, or represents that its use would not infringe privately owned rights. Reference herein to any specific commercial product, process, or service by trade name, trademark, manufacturer, or otherwise, does not necessarily constitute or imply its endorsement, recommendation, or favoring by the United States Government or any agency thereof or its contractors or subcontractors. The views and opinions of authors expressed herein do not necessarily state or reflect those of the United States Government or any agency thereof.

This report has been reproduced from the best available copy. 


\section{CONTENTS}

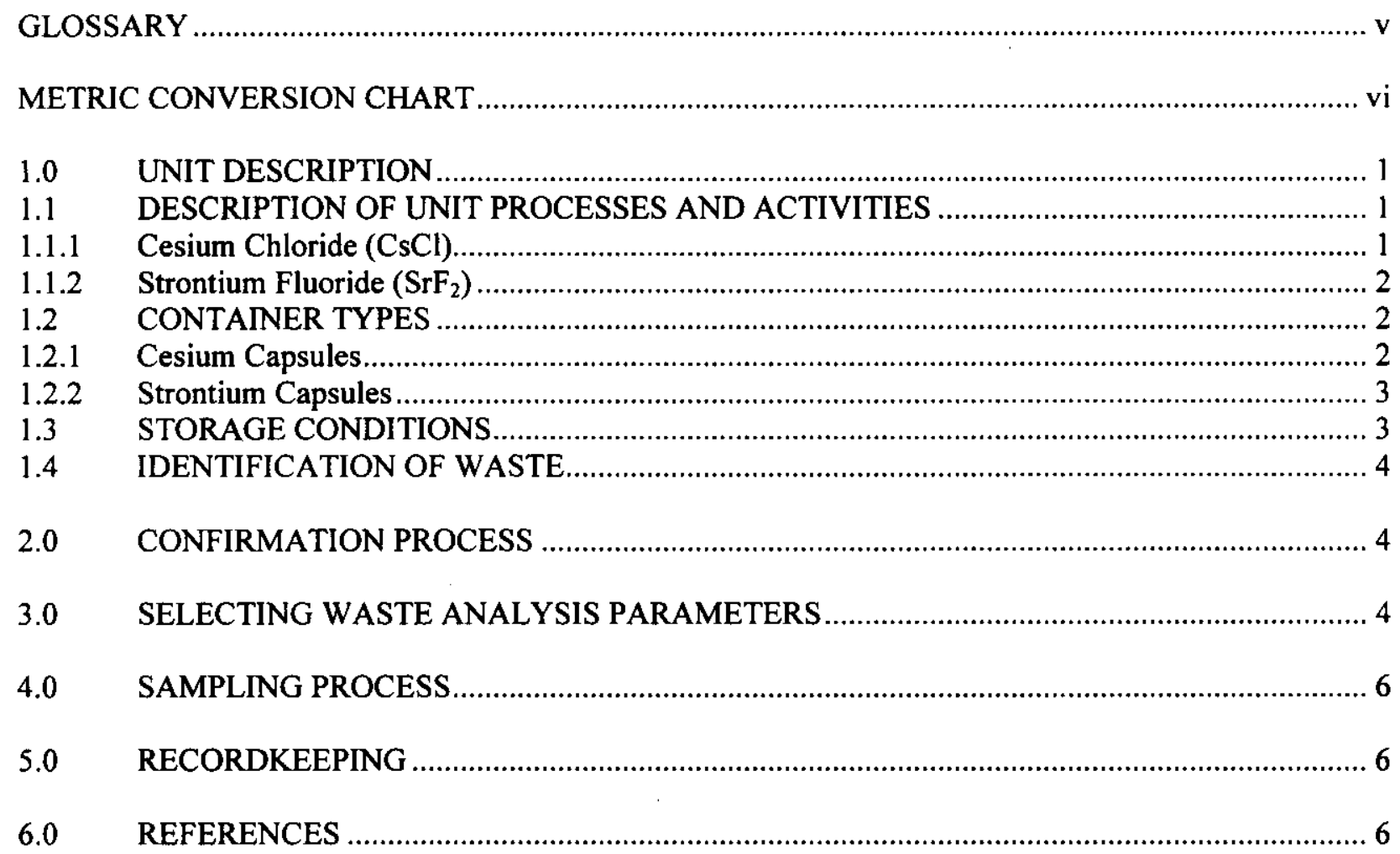

\section{ATTACHMENTS}

1 CERTIFICATION THAT CsCI POWDER AND PELLET MATERIALS MEET WESF ACCEPTANCE CRITERIA ATT 1-i

2 CERTIFICATION THAT UNOPENED TYPE 4 CONTAINER OF CSCI IS ACCEPTABLE FOR PACKAGING DIRECTLY INTO TYPE W OVERPACK ATT 2-i

\section{FIGURES} . ,

\section{.} 3 4 4 6 6 6 
HNF-7342

1

2

3

4

5

This page intentionally left blank. 
HNF-7342

${ }^{\circ} \mathrm{C}$
$\mathrm{CsCl}$
$\mathrm{CsCO}_{3}$
$\mathrm{HNF}$
$\mathrm{SrF}_{2}$
$\mathrm{Sr}\left(\mathrm{NO}_{3}\right)_{2}$

$\mathrm{Tri}^{-P a r t y}$ Agreemen
WAC
WAP
WESF

\section{GLOSSARY}

degrees Centigrade

cesium chloride

cesium carbonate

Hanford Nuclear Facility (document identifier)

strontium fluoride

strontium nitrate

Hanford Federal Facility Agreement and Consent Order

Washington Administrative Code

waste analysis plan

Waste Encapsulation and Storage Facility 


\section{METRIC CONVERSION CHART}

Into metric units

Out of metric units

\begin{tabular}{|c|c|c|c|c|c|}
\hline If you know & Multiply by & To get & If you know & Multiply by & To get \\
\hline \multicolumn{3}{|c|}{ Length } & \multicolumn{3}{|c|}{ Length } \\
\hline inches & 25.40 & millimeters & millimeters & 0.0393 & inches \\
\hline inches & 2.54 & centimeters & centimeters & 0.393 & inches \\
\hline feet & 0.3048 & meters & meters & 3.2808 & feet \\
\hline yards & 0.914 & meters & meters & 1.09 & yards \\
\hline miles & 1.609 & kilometers & kilometers & 0.62 & miles \\
\hline \multicolumn{3}{|c|}{ Area } & \multicolumn{3}{|c|}{ Area } \\
\hline square inches & 6.4516 & $\begin{array}{l}\text { square } \\
\text { centimeters }\end{array}$ & $\begin{array}{l}\text { square } \\
\text { centimeters }\end{array}$ & 0.155 & $\begin{array}{l}\text { square } \\
\text { inches }\end{array}$ \\
\hline square feet & 0.092 & square meters & square meters & 10.7639 & square feet \\
\hline square yards & 0.836 & square meters & square meters & 1.20 & square yards \\
\hline square miles & 2.59 & $\begin{array}{l}\text { square } \\
\text { kilometers }\end{array}$ & $\begin{array}{l}\text { square } \\
\text { kilometers }\end{array}$ & 0.39 & square miles \\
\hline acres & 0.404 & hectares & hectares & 2.471 & acres \\
\hline \multicolumn{3}{|c|}{ Mass (weight) } & \multicolumn{3}{|c|}{ Mass (weight) } \\
\hline ounces & 28.35 & grams & grams & 0.0352 & ounces \\
\hline pounds & 0.453 & kilograms & kilograms & 2.2046 & pounds \\
\hline short ton & 0.907 & metric ton & metric ton & 1.10 & short ton \\
\hline \multicolumn{3}{|c|}{ Volume } & \multicolumn{3}{|c|}{ Volume } \\
\hline fluid ounces & 29.57 & milliliters & milliliters & 0.03 & fluid ounces \\
\hline quarts & 0.95 & liters & liters & 1.057 & quarts \\
\hline gallons & 3.79 & liters & liters & 0.26 & gallons \\
\hline cubic feet & 0.03 & cubic meters & cubic meters & 35.3147 & cubic feet \\
\hline cubic yards & 0.76456 & cubic meters & cubic meters & 1.308 & cubic yards \\
\hline \multicolumn{3}{|c|}{ Temperature } & \multicolumn{3}{|c|}{ Temperature } \\
\hline Fahrenheit & $\begin{array}{l}\text { subtract } 32 \\
\text { then } \\
\text { multiply by } \\
\text { 5/9ths }\end{array}$ & Celsius & Celsius & $\begin{array}{l}\text { multiply by } \\
9 / 5 \text { ths, then } \\
\text { add } 32\end{array}$ & Fahrenheit \\
\hline \multicolumn{3}{|c|}{ Energy } & \multicolumn{3}{|c|}{ Energy } \\
\hline kilowatt hour & 3,412 & $\begin{array}{l}\text { British thermal } \\
\text { unit }\end{array}$ & $\begin{array}{l}\text { British thermal } \\
\text { unit }\end{array}$ & 0.000293 & $\begin{array}{l}\text { kilowatt } \\
\text { hour }\end{array}$ \\
\hline kilowatt & 0.948 & $\begin{array}{l}\text { British thermal } \\
\text { unit per second }\end{array}$ & $\begin{array}{l}\text { British thermal } \\
\text { unit per second }\end{array}$ & 1.055 & kilowatt \\
\hline \multicolumn{3}{|c|}{ Force/Pressure } & \multicolumn{3}{|c|}{ Force/Pressure } \\
\hline $\begin{array}{l}\text { pounds per } \\
\text { square inch }\end{array}$ & 6.895 & Kilopascals & kilopascals & 0.14504 & $\begin{array}{l}\text { pounds per } \\
\text { square inch }\end{array}$ \\
\hline
\end{tabular}

Source: Engineering Unit Conversions, M. R. Lindeburg, PE., Second Ed., 1990, Professional Publications, Inc., Belmont, California. 
HNF-7342

\section{WASTE ENCAPSULATION AND STORAGE FACILITY \\ WASTE ANALYSIS PLAN}

\subsection{UNIT DESCRIPTION}

The purpose of this waste analysis plan (WAP) is to document waste analysis activities associated with the Waste Encapsulation and Storage Facility (WESF) to comply with Washington Administrative Code (WAC) 173-303-300(1), (2), (3), (4), (5), and (6). WESF is an interim status other storage-miscellaneous storage unit. WESF stores mixed waste consisting of radioactive cesium and strontium salts. WESF is located in the 200 East Area on the Hanford Facility (Figure 1). Because dangerous waste does not include source, special nuclear, and by-product material components of mixed waste, radionuclides are not within the scope of this documentation. The information on radionuclides is provided only for general knowledge.

\subsection{DESCRIPTION OF UNIT PROCESSES AND ACTIVITIES}

Only waste stored in capsules identified in the Hanford Federal Facility Agreement and Consent Order (Tri-Party Agreement) (Ecology et al. 1999) milestone M-92-03 are stored at WESF. No waste has been received into WESF since the return of the capsules to meet M-92-03. Before receipt of any additional waste at WESF, a revision to this WAP will be required.

WESF (225B Building) is a two-story building constructed of steel reinforced concrete, is partitioned into seven hot cells, the hot cell service area, operating areas, building service areas and the pool cell area. The treatment, storage, and/or disposal (TSD) unit boundary includes only the hot cells $\mathrm{F}$ and $\mathrm{G}$, along with pool cells 1 through 8 and 12 (Figure 2).

The seven hot cells are labeled $A$ through $G$ and activities within the hot cells are performed remotely using manipulators. Only hot cells $\mathrm{F}$ and $\mathrm{G}$ are active for cesium/strontium capsule storage. The pool cell area consists of 12 pools lined with stainless steel. Each pool is equipped with a monitoring system to detect any leakage from capsules. Pool cells 1 through 8 and 12 can be used for capsule storage and are filled with water to a depth of approximately 4 meters ( $13 \mathrm{feet}$ ). The water provides cooling and shielding for the capsules.

The waste is stored in capsules consisting of stainless steel containers that provide primary and secondary containment. The maximum outer containment height is approximately 53 centimeters $(\sim 21$ inches $)$ with a maximum diameter of approximately 8 centimeters $(-3$ inches $)$.

Only one waste stream is managed at WESF, which consists of the cesium chloride ( $\mathrm{CsCl}$ ) and strontium fluoride $\left(\mathrm{SrF}_{2}\right)$ salts that are stored within the capsules in the pool cells.

Additional information is located in the WESF Part A, Form 3, in the Hanford Facility Dangerous Waste Part A Permit Application (DOE/RL-88-21).

\subsubsection{Cesium Chloride (CsCl)}

Cesium was separated in B Plant from high-level waste generated in the reprocessing of the spent fuel on the Hanford Site. This separation process, also known as fractionization, was performed to remove the high-heat producing isotope cesium (cesium-137) from the underground tank waste on the Hanford Site to 
reduce the heat burden to the underground tanks. The fractionization process at $\mathrm{B}$ Plant purified the cesium in the form of cesium carbonate $\left(\mathrm{CsCO}_{3}\right)$. The purified $\mathrm{CsCO}_{3}$ was transferred to WESF and converted to $\mathrm{CsCl}$ by addition of hydrochloric acid. This $\mathrm{CsCl}$ solution was evaporated to a molten salt and encapsulated for long-term storage. The encapsulated salt contains dangerous waste chemical impurities from the fractionization process consisting of lead, barium, chromium, cadmium, and silver. Barium is generated continuously as a result of the cesium-137 decay chain.

\subsubsection{Strontium Fluoride $\left(\mathrm{SrF}_{2}\right)$}

Strontium was separated at B Plant from waste generated in the reprocessing of the spent fuel. The fractionization process removed the high-heat producing isotope strontium (strontium-90) from the underground tank waste on the Hanford Site and purified the strontium-90 in the form of strontium nitrate [Sr(NO$\left.)_{2}\right)_{2}$. The purified $\mathrm{Sr}\left(\mathrm{NO}_{3}\right)_{2}$ was transferred to WESF and converted to $\mathrm{SrF}_{2}$ by the addition of sodium fluoride. The $\mathrm{SrF}_{2}$ precipitate was filtered and dried at $800^{\circ} \mathrm{C}$ and encapsulated for long-term storage. The encapsulated salt contains dangerous waste chemical impurities from the fractionization process consisting of barium, lead, cadmium, chromium, and silver.

\subsection{CONTAINER TYPES}

The $\mathrm{CsCl}$ and $\mathrm{SrF}_{2}$ salts are stored in three types of containers at WESF: cesium capsules, strontium capsules, and Type W capsules. Cesium is stored in both the cesium capsules and Type W capsules. Strontium is stored only in strontium type capsules.

\subsubsection{Cesium Capsules}

Two types of cesium capsules are stored at WESF. The standard cesium capsule consists of a double capsule configuration of a capsule placed inside another as shown in Figure 3. Both capsules are constructed of 316L stainless steel. The inner capsule dimensions are 5.7 centimeters ( 2.25 inches) in diameter by 50.1 centimeters ( 19.725 inches) long. The inner capsule has a nominal wall thickness of 0.24 centimeter $(0.095$ inch). The outer capsule is 6.7 centimeters ( 2.625 inches) in diameter by 52.8 centimeters ( 20.725 inches) long. The outer capsule has a nominal wall thickness of 0.28 centimeter $(0.109$ inch). There are a total of 1,312 standard cesium capsules in storage.

The Type W cesium capsule is a 316L stainless steel overpack used to contain standard cesium capsules that had swollen as a result of thermal cycling, cesium chloride that had been reconfigured into pencils or pellets for use as irradiators, or the contents of capsules that had been cut up for examination purposes. The Type $\mathrm{W}$ capsule is 8.3 centimeters ( 3.25 inches) in diameter by 55.4 centimeters ( 21.8 inches) long. The capsule has a nominal wall thickness of 0.32 centimeter $(0.13$ inch). There are a total of 23 Type W capsules in storage. Table 1 shows a breakdown of the Type $\mathrm{W}$ capsules and contents. 
HNF-7342

Table 1. Type W Capsules and Contents.

\begin{tabular}{|l|c|c|c|}
\hline \multicolumn{1}{|c|}{ Capsule contents } & Inner capsule & Outer capsule & $\begin{array}{c}\text { Number of } \\
\text { Type } W\end{array}$ \\
\hline $\begin{array}{l}\text { 10 Nordiant } \\
\text { containing CsCl originating from WESF }\end{array}$ & Yes & Yes & 1 \\
\hline $\begin{array}{l}\text { Cesium chloride powder and/or pellets from } \\
\text { Oak Ridge }\end{array}$ & Yes & Yes & 2 \\
\hline $\begin{array}{l}\text { 304L stainless steel type 4 containers from } \\
\text { Oak Ridge containing CsCl originating from } \\
\text { WESF }\end{array}$ & No & No & 1 \\
\hline $\begin{array}{l}\text { Remnants from destructive testing of WESF } \\
\text { capsules }\end{array}$ & No & Yes & 3 \\
\hline $\begin{array}{l}\text { Swollen WESF capsules returned from } \\
\text { commercial irradiators }\end{array}$ & Yes & Yes & 16 \\
\hline Total & & & 23 \\
\hline
\end{tabular}

The salts encapsulated in the Nordian ${ }^{\mathrm{TM}}$ pencils, powder and pellets, and Type 4 canisters were washed (Attachment 1) at Oak Ridge to remove impurities.

Compatibility and corrosion of 304L versus 316L SS was evaluated and determined to be acceptable for storage at WESF (Attachment 2).

\subsubsection{Strontium Capsules}

Two types of material are used to encapsulate the $\mathrm{SrF}_{2}$. Like the standard cesium capsule, the strontium capsule consists of a capsule within a capsule as shown in Figure 4. The inner capsule is Hastelloy $\mathrm{C}-276^{2}$. The outer capsule for all strontium capsules is $316 \mathrm{~L}$ stainless steel. These two metals are compatible in terms of galvanic corrosion in that the metals are within the same range in the galvanic series and are not exposed to an electrically conducting solution (Chemical Engineer's Handbook). The inner capsule is 5.7 centimeters ( 2.25 inches) in diameter by 48.4 centimeters ( 19.05 inches) long. The outer capsule is 6.7 centimeters ( 2.625 inches) in diameter by 51.1 centimeters ( 20.1 inches) long. There are a total of 601 standard strontium capsules in storage.

\subsection{STORAGE CONDITIONS}

WESF is permitted for storage of the capsules in either the hot cells or the pool cells. There are 1,936 capsules currently stored in the pool cells at WESF. All of the capsules are stored in the pool cells under 4 meters ( 13 feet) of water for shielding and cooling. Leak detection for the capsules consists of an online monitoring system. A monitor is in place on the circulation line for each pool cell. The monitoring system is calibrated to detect cesium-137 at 1.74 becquerels per milliliter (47.2 $\times 10^{-6}$ microcuries per milliliter) and strontium- 90 at 0.87 becquerels per milliliter (23.6 $\times 10^{-6}$ microcuries per milliliter). This equates to 0.28 parts per trillion or $3.2 \times 10^{-3}$ parts per trillion respectively for the associated dangerous waste constituent barium in the cesium and strontium salts.

\footnotetext{
${ }^{1}$ Trademark of MDS Nordian, Inc. Kanata, Ontario, Canada.

${ }^{2}$ Trademark of Haynes International, Inc., Kokomo, Indiana.
} 


\subsection{IDENTIFICATION OF WASTE}

The Part A, Form 3, permit application for WESF (DOE/RL-88-21) identifies dangerous waste numbers, quantities, and design capacity. Waste numbers were assigned based on process knowledge that included previously obtained sampling and analysis results and process flow sheet specifications of WESF waste.

\subsection{CONFIRMATION PROCESS}

WAC 173-303-300 (3) and 300(6) require information be obtained, documented, and/or reported regarding waste accepted into WESF. All of the waste in storage at WESF originated at WESF. WESF does not receive waste from an offsite facility; therefore, no additional information or analysis is required to meet WAC 173-303-300(3) and 300(6). Any additional waste accepted into WESF will require a revision to this WAP.

\subsection{SELECTING WASTE ANALYSIS PARAMETERS}

Capsules have been stored in WESF since 1974. The parameter for safe storage of the capsules is corrosion of the containers from contact with impurities contained in the cesium and strontium salts. Studies were completed by Pacific Northwest National Laboratory confirming safe storage of the capsules through 2017 under current storage conditions (PNL-5170 and BNWL 1967). The information from these studies along with the following information meets the intent of WAC 173-303-300(5a) and (b). WAC 173-303-610(4)(d) does not apply to WESF.

Impurities in the cesium salt are estimated as listed in PNL-5170. The following data were taken on cesium feed solution and salt analyzed for corrosion analysis. Concentrations are listed as weight percent solids. Silver was added from process knowledge.

\begin{tabular}{|l|c|c|}
\hline \multicolumn{1}{|c|}{ Element } & $\begin{array}{c}\text { Cesium feed } \\
\text { solution Wt\% }\end{array}$ & Salt analysis Wt\% \\
\hline $\mathrm{Al}$ & 1.7 & .14 \\
\hline $\mathrm{B}$ & -- & .14 \\
\hline $\mathrm{Ba}$ & .94 & .55 \\
\hline $\mathrm{Ca}$ & 1. & -- \\
\hline $\mathrm{Cd}$ & -- & .02 \\
\hline $\mathrm{Co}$ & -- & .1 \\
\hline $\mathrm{Cr}$ & .27 & 1.4 \\
\hline $\mathrm{Fe}$ & .38 & -- \\
\hline $\mathrm{K}$ & .79 & .68 \\
\hline $\mathrm{Mg}$ & .25 & .68 \\
\hline $\mathrm{Na}$ & .70 & 2.8 \\
\hline $\mathrm{Ni}$ & .33 & .1 \\
\hline $\mathrm{Pb}$ & 1.4 & .14 \\
\hline $\mathrm{Rb}$ & .52 & -- \\
\hline $\mathrm{Si}$ & 7 & .21 \\
\hline $\mathrm{Sr}$ & .18 & .02 \\
\hline $\mathrm{Ti}$ & -- & .02 \\
\hline $\mathrm{Zn}$ & -- & .03 \\
\hline
\end{tabular}


Impurities in the cesium salts washed at Oak Ridge are listed in HNF-2928 "Certification that CsCl Powder and Pellet Materials Meet WESF Acceptance Criteria". The concentrations are listed as follows by weight percent.

\begin{tabular}{|l|c|}
\hline \multicolumn{1}{|c|}{ Element } & $\mathrm{Wt} \%$ \\
\hline $\mathrm{Al}$ & .68 \\
\hline $\mathrm{B}$ & 5.17 \\
\hline $\mathrm{Ba}$ & 2.98 \\
\hline $\mathrm{Ca}$ & .68 \\
\hline $\mathrm{Cu}$ & .02 \\
\hline $\mathrm{Fe}$ & .04 \\
\hline $\mathrm{K}$ & 1.21 \\
\hline $\mathrm{Mg}$ & .04 \\
\hline $\mathrm{Mo}$ & .009 \\
\hline $\mathrm{Na}$ & 7.76 \\
\hline $\mathrm{Ni}$ & .01 \\
\hline $\mathrm{Si}$ & 2.59 \\
\hline $\mathrm{Sr}$ & .01 \\
\hline $\mathrm{Zn}$ & .03 \\
\hline
\end{tabular}

6

7

8

9

10

11

Impurities in the strontium salt are estimated as listed in BNWL- 1967 "The Containment of ${ }^{90} \mathrm{SrF} 2$ at $800^{\circ} \mathrm{C}$ to $1100^{\circ} \mathrm{C}$ Preliminary Results" Battelle 1975. The data listed are estimates based on process flowsheet information. The concentrations are listed in weight percent.

\begin{tabular}{|l|c|}
\hline \multicolumn{1}{|c|}{ Element } & $\begin{array}{c}\text { Probable } \\
\text { concentration } \\
(\mathrm{Wt} \%)\end{array}$ \\
\hline $\mathrm{Al}$ & $<0.5$ \\
\hline $\mathrm{Ba}$ & $0.1-2.0$ \\
\hline $\mathrm{Ca}$ & $<0.1$ \\
\hline $\mathrm{Cd}$ & $<0.2$ \\
\hline $\mathrm{Cr}$ & $<0.1$ \\
\hline $\mathrm{Cu}$ & $<0.1$ \\
\hline $\mathrm{Fe}$ & $<0.01$ \\
\hline $\mathrm{H}$ & $<0.1$ \\
\hline $\mathrm{K}$ & $0.05-0.5$ \\
\hline $\mathrm{Mg}$ & $<0.1$ \\
\hline $\mathrm{Mn}$ & $<0.01$ \\
\hline $\mathrm{N}$ & $1-4$ \\
\hline $\mathrm{Na}$ & $<0.1$ \\
\hline $\mathrm{Ni}$ & $<0.05$ \\
\hline $\mathrm{Pb}$ & $<0.2$ \\
\hline $\mathrm{R}$ (as in Rare Earths) & $<2.0$ \\
\hline $\mathrm{Si}$ & $<0.02$ \\
\hline
\end{tabular}

This review meets the requirements of WAC 173-303-300(1) and (2) for WESF waste. This review confirms knowledge concerning waste before storage to ensure that the waste is managed properly. 
1 In addition, a certified database is maintained in the operating record that contains information on each

2 capsule from its origin to present storage location. The database is updated annually.

\subsection{SAMPLING PROCESS}

Periodic re-analysis of WESF waste managed in the WESF Storage Units based on WAC 173-303-300(5)(d), is not planned because the containers are sealed and no changes can be made to the salts. Therefore, WAC 173-303-300(4)(a) is not applicable to WESF waste.

The capsules are sealed containers whose constituents have been determined via the confirmation process in Section 2.0. No additional waste is planned or scheduled for storage at WESF. Therefore, requirements of WAC-173-303-300(5c),(d), (e), and (g) do not apply.

No additional requirements are specified in WAC 173-303-400(3); therefore, WAC 173-303-(5)(f) does not apply.

WESF is not a surface impoundment; therefore, WAC 173-303-300(5)(h) does not apply.

An exemption to the air emission standards of Subpart CC in accordance with Section 264.1082 or with 265.1083 is not being requested; therefore, WAC-173-303-300(5)(i) does not apply.

\subsection{RECORDKEEPING}

Records for WESF are maintained as described in WAC 173-303-380.

\subsection{REFERENCES}

BNWL-1967, 1975, "The Containment of ${ }^{90} \mathrm{SrF}_{2}$ at $800^{\circ} \mathrm{C}$ to $1100^{\circ} \mathrm{C}$ Preliminary Results", Battelle Northwest Laboratory, Richland, Washington.

DOE/RL-88-21, Hanford Facility Dangerous Waste Part A Permit Application, U.S. Department of Energy, Richland Operations Office, Richland, Washington.

Ecology, EPA, and DOE-RL, 1999, Hanford Federal Facility Agreement and Consent Order, Washington State Department of Ecology, U.S. Environmental Protection Agency, U.S. Department of Energy, Richland Operations Office, Olympia, Washington, amended periodically.

HNF-2928, 1998, "Certification that CsCl Powder and Pellet Materials Meet WESF Acceptance Criteria", B\&W Hanford Company, Richland, Washington.

PNL-5170, 1984, "A Review of Safety Issues that Pertain to the Use of WESF Cesium Chloride Capsules in an Irradiator", Pacific Northwest Laboratory, Richland, Washington. 


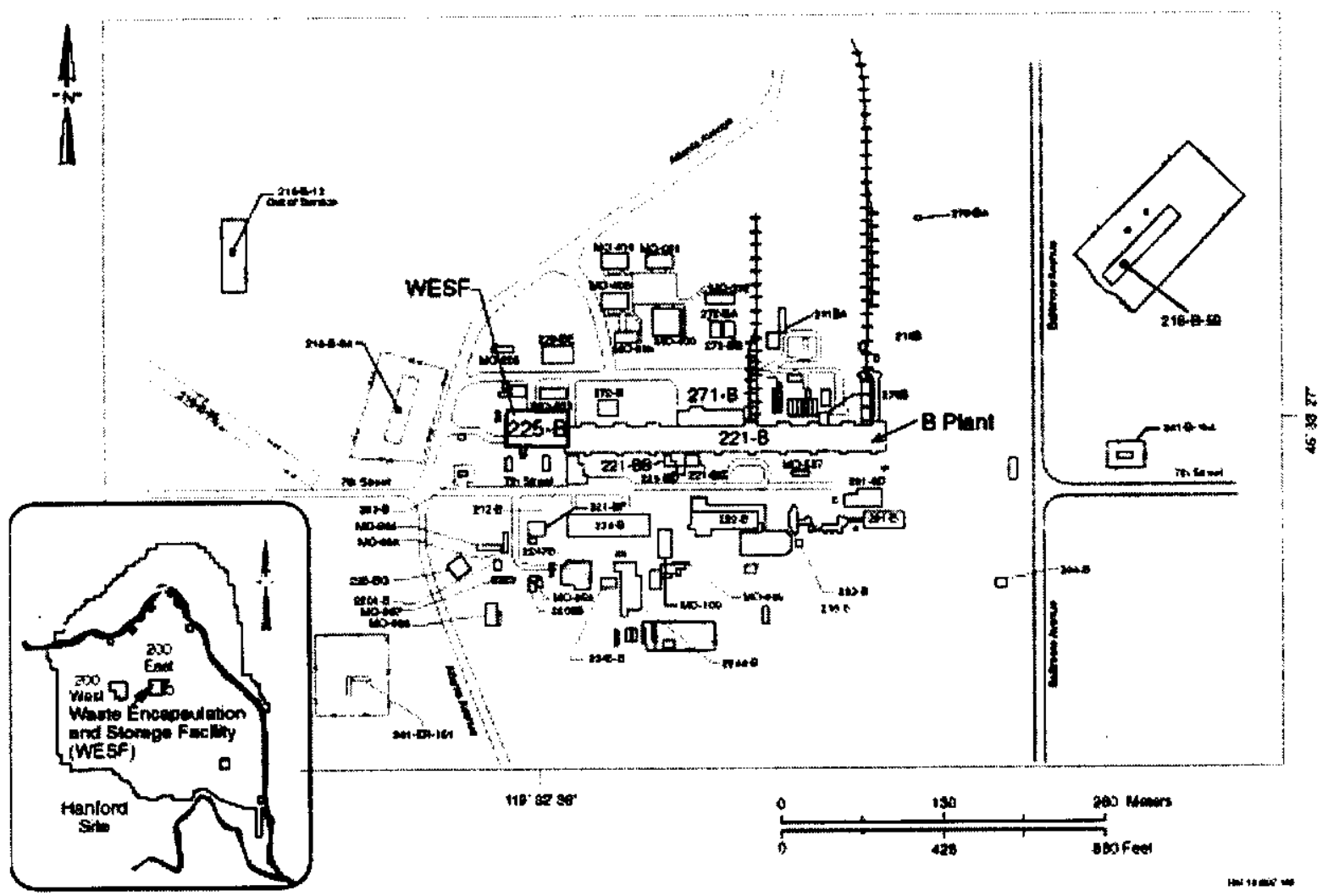

Figure 1. 200 East Area. 


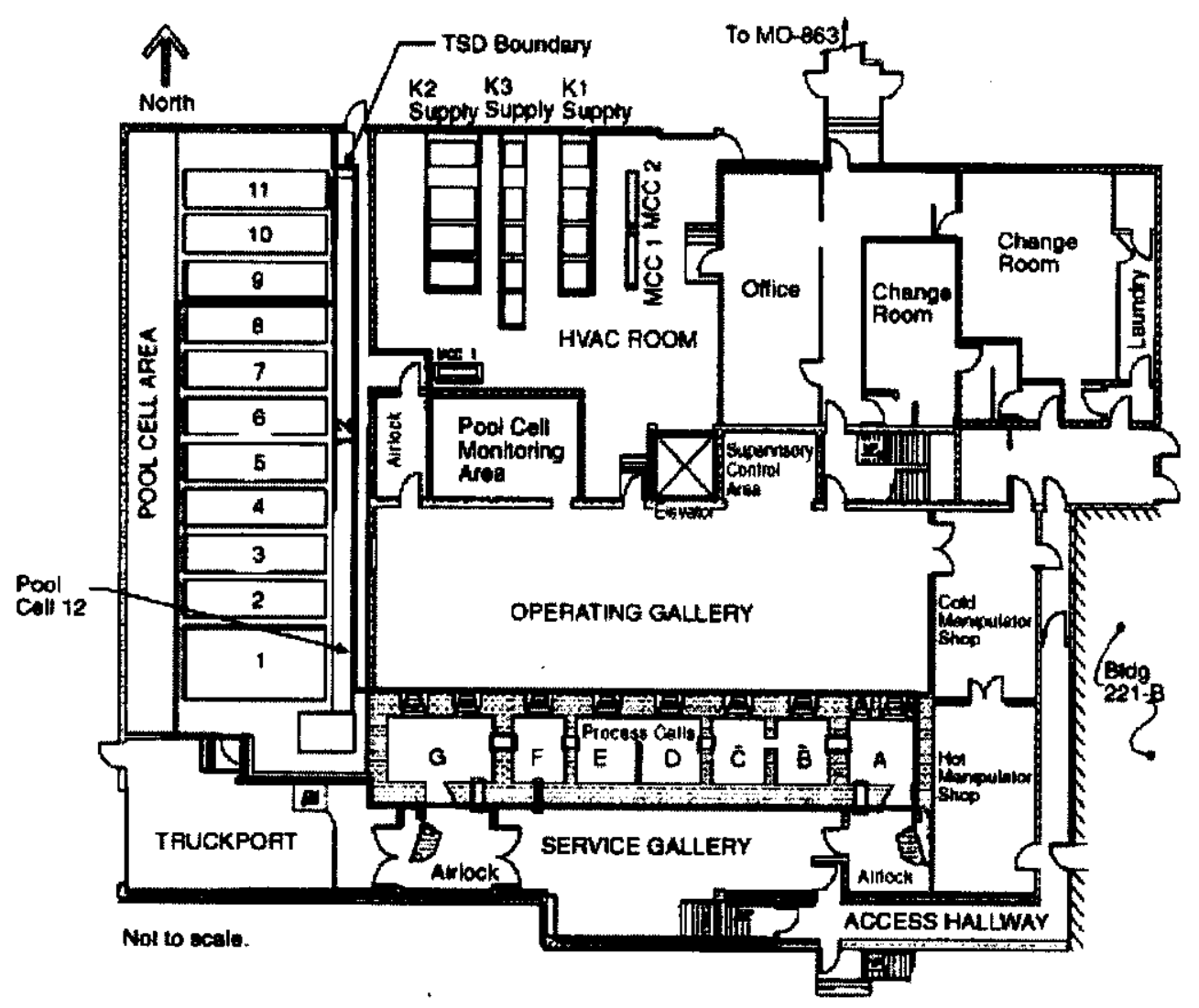

Hom10e03.2W

Figure 2. Waste Encapsulation and Storage Facility Treatment, Storage, and/or Disposal Boundaries. 


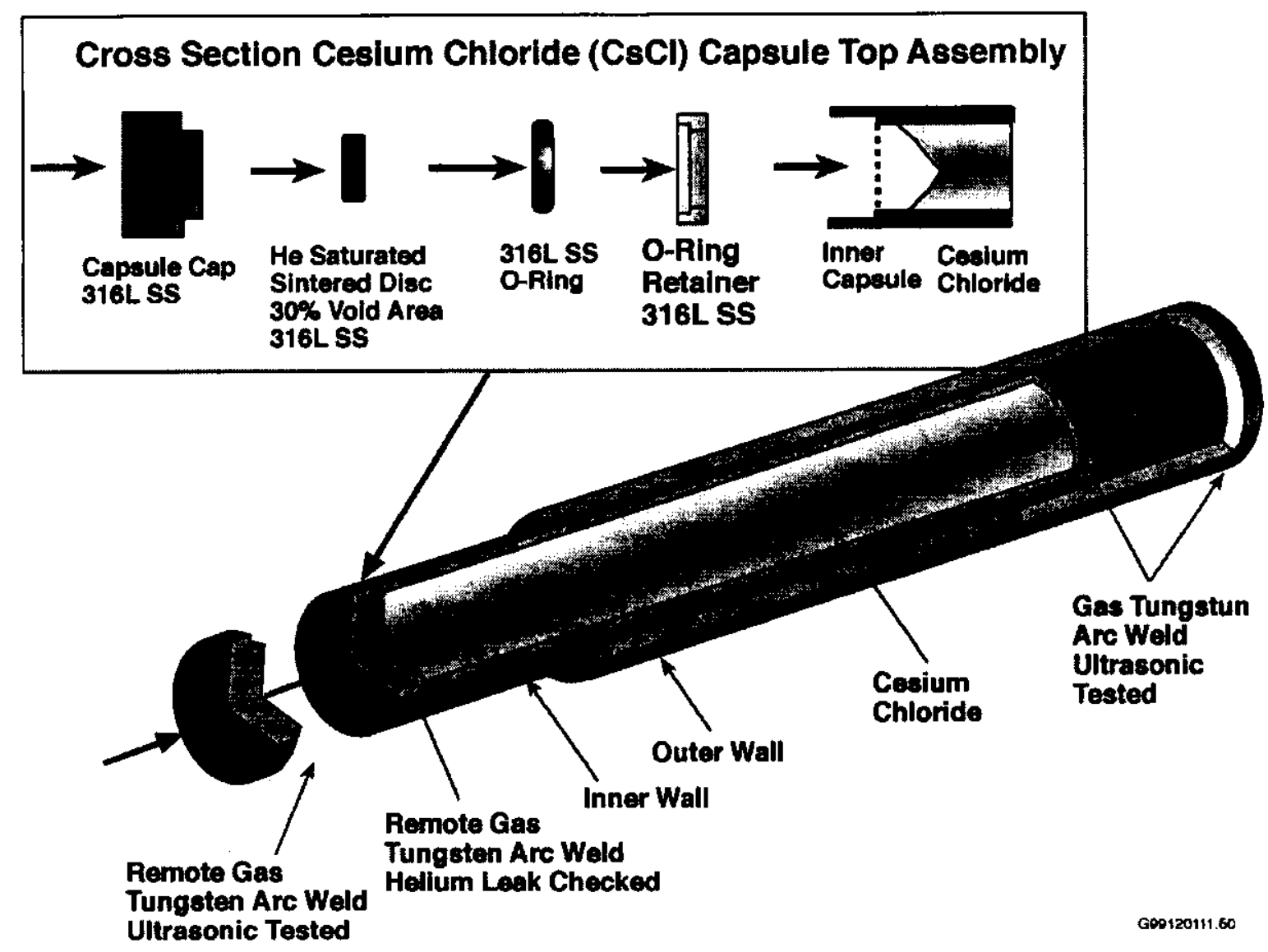

Figure 3. Standard Cesium Capsule. 


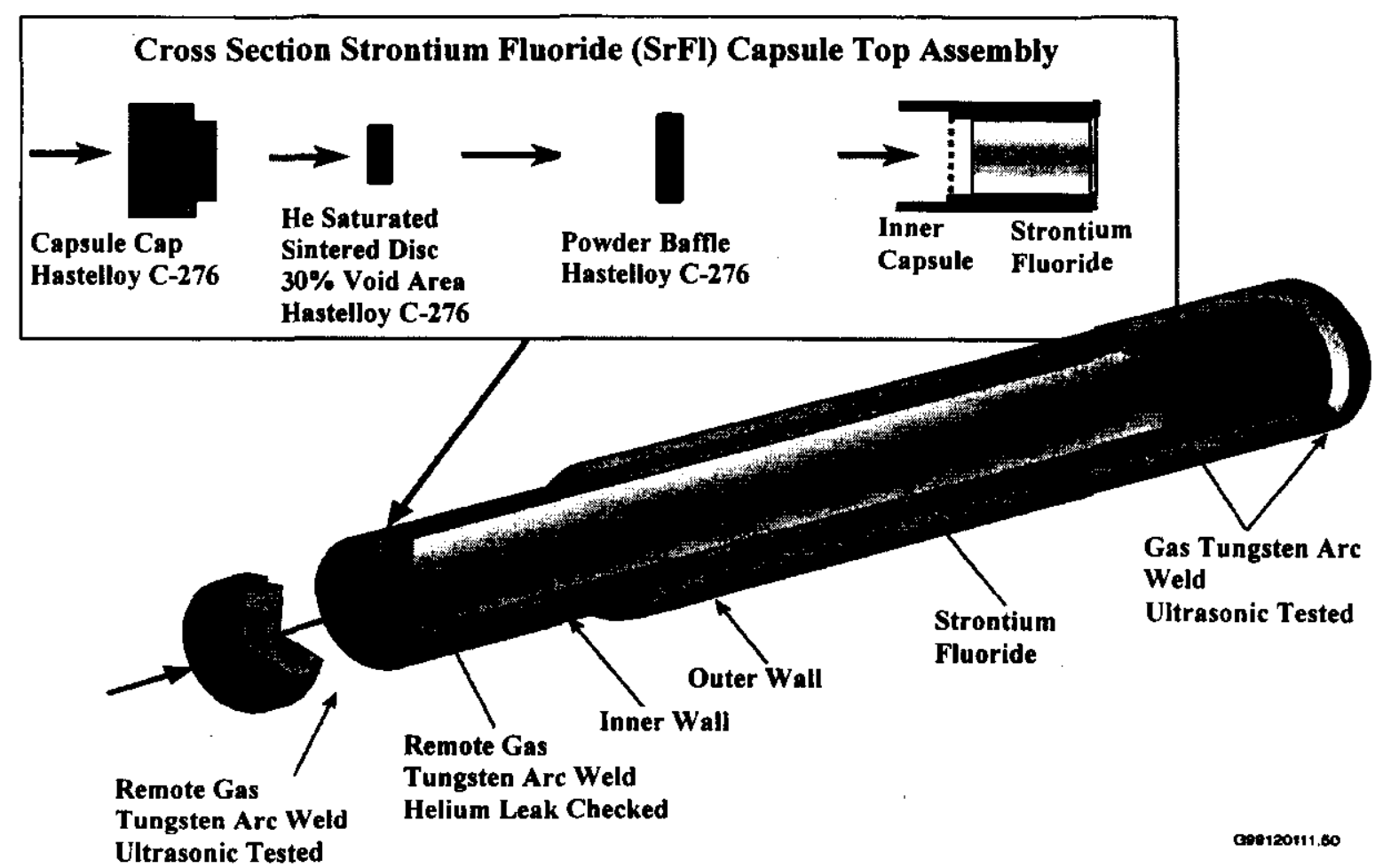

Figure 4. Standard Strontium Capsule. 
HNF-7342

\section{ATTACHMENT 1}

CERTIFICATION THAT CsCI POWDER AND PELLET MATERIALS MEET WESF ACCEPTANCE CRITERIA 
HNF-7342

This page intentionally left blank. 
JUN 361998

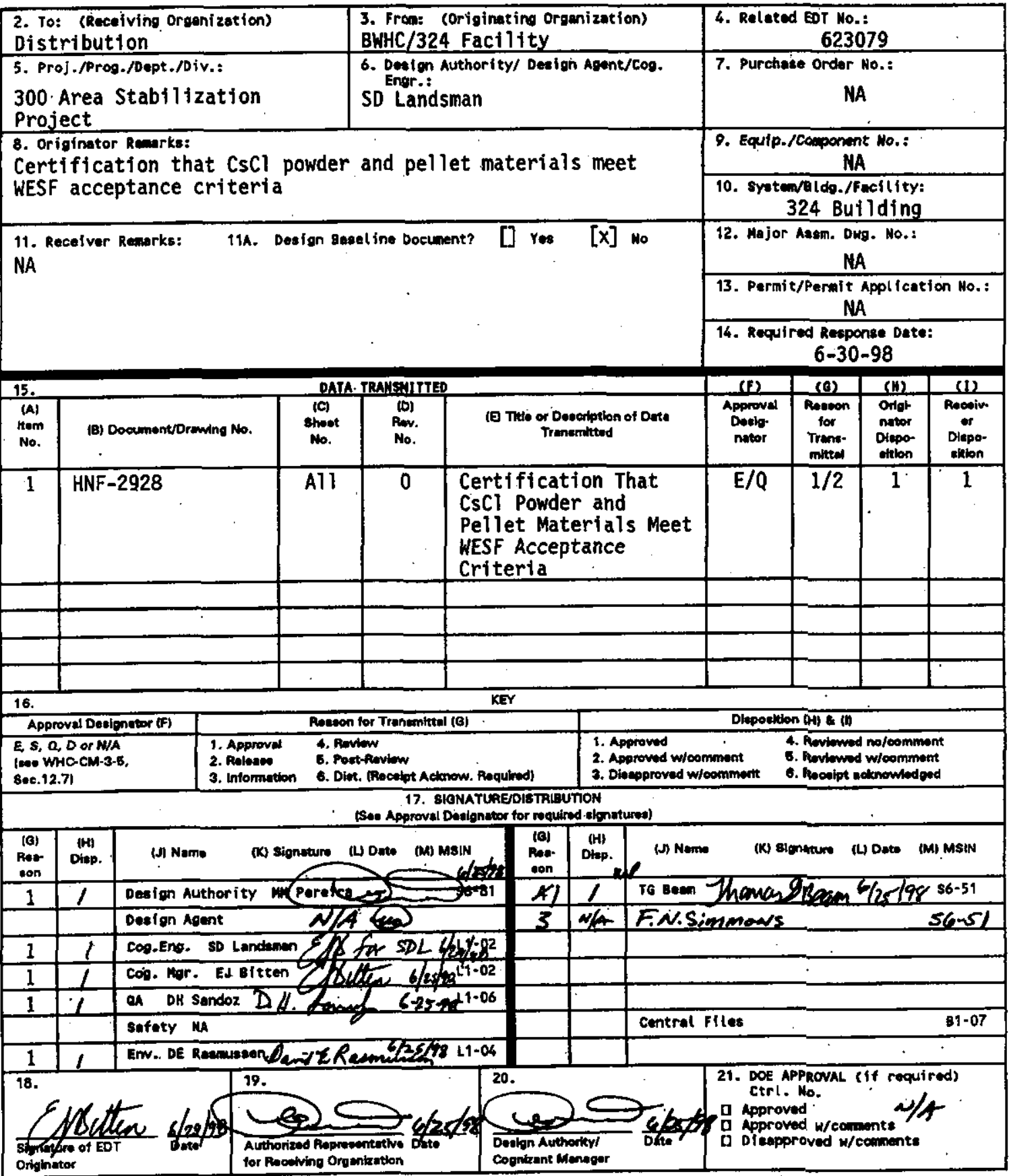

BD-7400-172-2 (05/96) GEF097 


\section{Certification That CsCl Powder and Pellet Materials Meet WESF Acceptance Criteria}

SD Landsman

BWHC, Richland, WA 99352

U.S. Department of Energy Contract DE-AC06-96RL13200

$\begin{array}{lll}\text { EDT/ECN: } & 625231 & \text { UC: } 2000 \\ \text { Org Code: } & 19350 & \text { Charge Code: } \\ \text { B\&RC21 Code: } & \text { EW7050000 } & \text { Total Pages: } 10 / / V .8\end{array}$

Key Words: Certification, CsCl Powder and Pellet Materials, WESF Acceptance Criteria

Abstract: This document describes the $\mathrm{CsCl}$ legacy material created by the Cesium Encapsulation Program (CEP) is acceptable for storage at WESF.

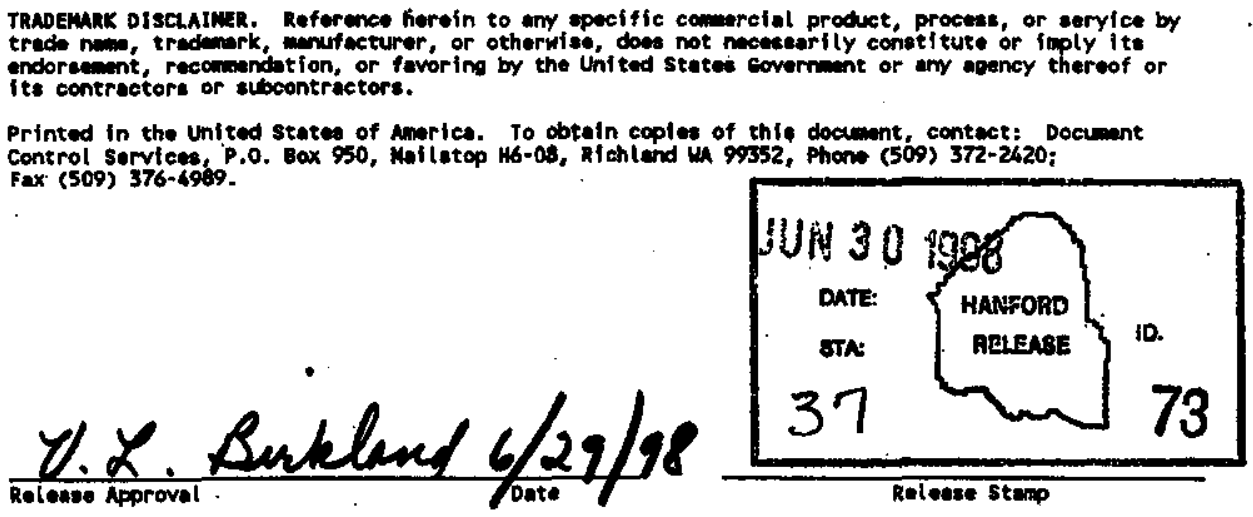

Approved for Public Release

A-6400-073 (01/97) OEF321 
HNF-2928, Rev 0

June 24, 1998

\section{Certification That the CsCl Powder and Pellot Material Meets WESF Acceptance Criteria}

This report documents that the $\mathrm{CsCl}$ that will be encapsulated into Inner Containers, WESF Outer Capsules, and WESF Type "W" Overpacks prior to shipping to WESF for long term storage is consistent with the material currently stored in the WESF pool cells. Process knowledge, analytical data, shipping records, and recent characterization smears obtained from South Cell are used as the basis for this conclusion. This letter describes the condition of the cell in which the $\mathrm{CsCl}$, collectively called powder and pellets, was handled and the environment to which it has been exposed, the containers in which the powder and pellets have been stored to date, and the physical form and purity of the $\mathrm{CsCl}$ comprising the powder and peliets. The powder and pellets are legacy material created by the Cesium Encapsulation Program (CEP) and destructive analysis of two WESF capsules.

\section{Storage Container Description}

The $\mathrm{CsCl}$ powder and pellets are stored in release resistant containers. These containers are mechanically closed with a metallic seal. Although the release resistant container is not a special form or normal form container, it is a strong tight container. The containers housing the powder and pellets have not been involved in accidents, have not been dropped, and have not been subjected to chemically harsh environments. in October 1996 a visual inventory of the containers was performed and the powder and pellets were transferred to new release resistant containers. The containers are currently stored in D Cell in a shielded box fabricated speclifically for storage of the $\mathrm{CsCl}$. Prior to encapsulation of the powder and pellets, the containers will be returned to South Cell where they will be opened.

\section{Description of $\mathrm{CsCl}$}

The CsCl to be packaged for shipment to WESF consists of caked powder, pelletized powder; chunks, and singly-encapsulated pellets. There are two distinct groups of material comprising the powder and pellets: material recovered from the destructive analysis of two WESF capsules (C-1502 and C-1550) and material that was purified for use in the Cesium Encapsulation Program (CEP). During packaging of the powder and pellets for shipment to WESF, separation of the two groups of material will be maintained.

The first group of $\mathrm{CsCl}$ is the residual material resulting from the destructive analysis of capsule C-1502, which leaked CsCl at RSI-Atlanta. This project is described in the draft report "Destructive Examination Program Cesium Capsule C1502 Report" by Oakley, Tingey, and Tingey (Attachment 1). The analysis involved removing the WESF 
HNF-2928, Rev 0 June 29, 1998

Outer Capsule and sectioning the WESF Inner Capsule, including the CsCl. Prior to sectioning of C-1502, C-1550 (a "sister" capsule to C-1502) was sectioned as practice. Sectioning of C-1502 occurred on September 29, 1992. After sectioning, the chunks of $\mathrm{CsCl}$ (approximately $80,000 \mathrm{Ci}$ ) were placed into release resistant containers and sealed.

The second group of $\mathrm{CsCl}$ is legacy material from the CEP. This physical form of this material is $13,400 \mathrm{Cl}$ of pelletized $\mathrm{CsCl}$ (two sizes of pellets: $1-3 / 8^{\prime \prime}$ diameter $\times 5 / 8^{\prime \prime}$ and $5 / 16^{\prime \prime}$ diameter $\times 5 / 16^{\prime \prime}$ ) in release resistant containers, $10,800 \mathrm{Ci}$ of powder in an unopened Type 4 shipping container (this material is presumed to be caked into a solid block), and $4400 \mathrm{Ci}$ of small pellets in 10 singly-encapsulated Nordian capsules. Work with CsCl in South Cell in support of the CEP was initiated on October 9, 1991 and prematurely terminated on April 22, 1992. All handling of the CEP CsCl was performed in South Cell Compartment 1; the material has been stored in release resistant containers since the program was terminated. Material involved with the CEP was purified at Oak Ridge prior to shipment to the Shielded Materials Facility (SMF). Consequently, the $\mathrm{CsCl}$ associated with the $\mathrm{CEP}$ is purer than the $\mathrm{CsCl}$ that is encapsulated and stored at WESF. This material will be maintained and packaged separately from the material generated during destructive analysis of the WESF capsules.

\section{Handling Cell Description}

The SMF South Cell Compartment 1 was used for all handling activities associated with the powder and pellets. Compartment 1 was constructed in South Cell when the dose rates were low enough to allow personnel entry into the cell. Historically, South Cell has remained an alpha-free cell. As a result of the CEP, the dose rates in South Cell now average $11 \mathrm{rem} / \mathrm{h}$ and the dose rates in compartment 1 are 11,000 rem/h, all from $\mathrm{CsCl}$ contamination. Handling of unclad fuel or other material containing dispersible alpha-emitting radionuclides has not occurred in any of the compartments or in South Cell proper. A detailed contamination survey was performed in May 1989 which verified the SMF is free of alpha contamination. (Reference HNF-2849)

\section{Comparison with WESF CsCl}

The CsCl from Capsules C-1502 and. C-1550 is consistent with the CsCl currently stored at WESF. Analytical data obtained as part of the CEP demonstrates that the $\mathrm{CsCl}$ from this program is of higher purity than WESF CsCl because the $\mathrm{CsCl}$ was water-washed at Oak Ridge National Laboratory (ORNL) prior to its shipment to the SMF. The analytical report for $\mathrm{CsCl}$ batch $\mathrm{C}-1542$, which comprises the powder and pellets, is provided in Attachment 2 and demonstrates that material processing at. ORNL reduced the amount of contaminants in the $\mathrm{CsCl}$ and did not add other 
HNF-2928, Rev $0^{\circ}$

June 24, 1998

contaminants. Therefore, the powder and pellets are bounded by the current WESF corrosion studies and associated design basis.

The CsCl powder and pellets originated from WESF and was shipped to the SMF either via ORNL (material from the CEP) or directly (remnants from destructive examination). The shipping records for $\mathrm{C}-1502$ and $\mathrm{C}-1550$ are provided in Attachment 3. No foreign material was added to this material and the contamination in Compartment 1 was a result of the CEP and the two destructive analyses; the remainder of South Cell has been maintained as an alpha-free facility. Consequently, no other radionuclide or form of $\mathrm{Cs}$ could have contaminated the $\mathrm{CsCl}$. Recent characterization smears taken in South Cell have verified that the entire SMF is free of alpha-emitters (HNF-2849) and that waste removed from these cells would not be designated as TRU waste.

Therefore, the powder and pellets, including the remnants from destructive examination of two WESF capsules, is consistent with WESF CsCl and is within the WESF Part A permit.

\section{Conclușion}

Based on process knowledge and the data provided in this report, it can be concluded that the $\mathrm{CsCl}$ powder and pellets are consistent with the material currently stored at WESF. In addition, process knowledge and the SMF characterization study demonstrate that the material is not contaminated with alpha contamination: Therefore, the powder and pellet material is bounded by the WESF corrosion studies and associated design basis and the material is not TRU waste. Storage of this material at WESF will not violate the WESF safety basis and is covered by the WESF Part A permit. 
HNF-7342

$\cdots$

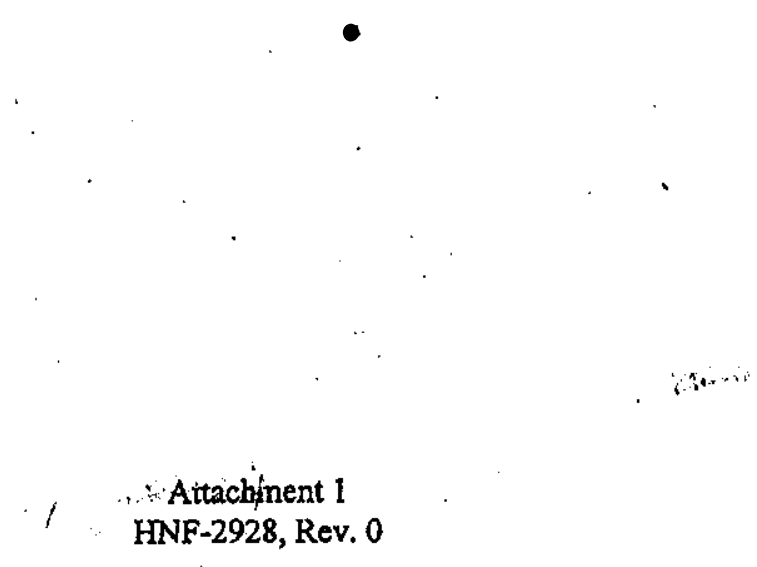

HNF-2928, Rev. 0 
HNF-7342

DESTRUCTIVE EXAMINATION PROGRAM

CESIUM CAPSULE C1502 REPORT

David J. Oakley

Garth L. Tingey

Joe? $M$. Tingey

December 1993

Prepared for

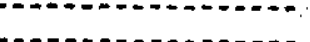

under Contract

Battel]e, Pacific Northwest Laboratories

Richland, Washington 99352 
HNF-7342

Attachment 2

HNF-2928, Rev. 0 
HNF-2928, Rev. 0

tCP Anulysis Report

K.E. Ard

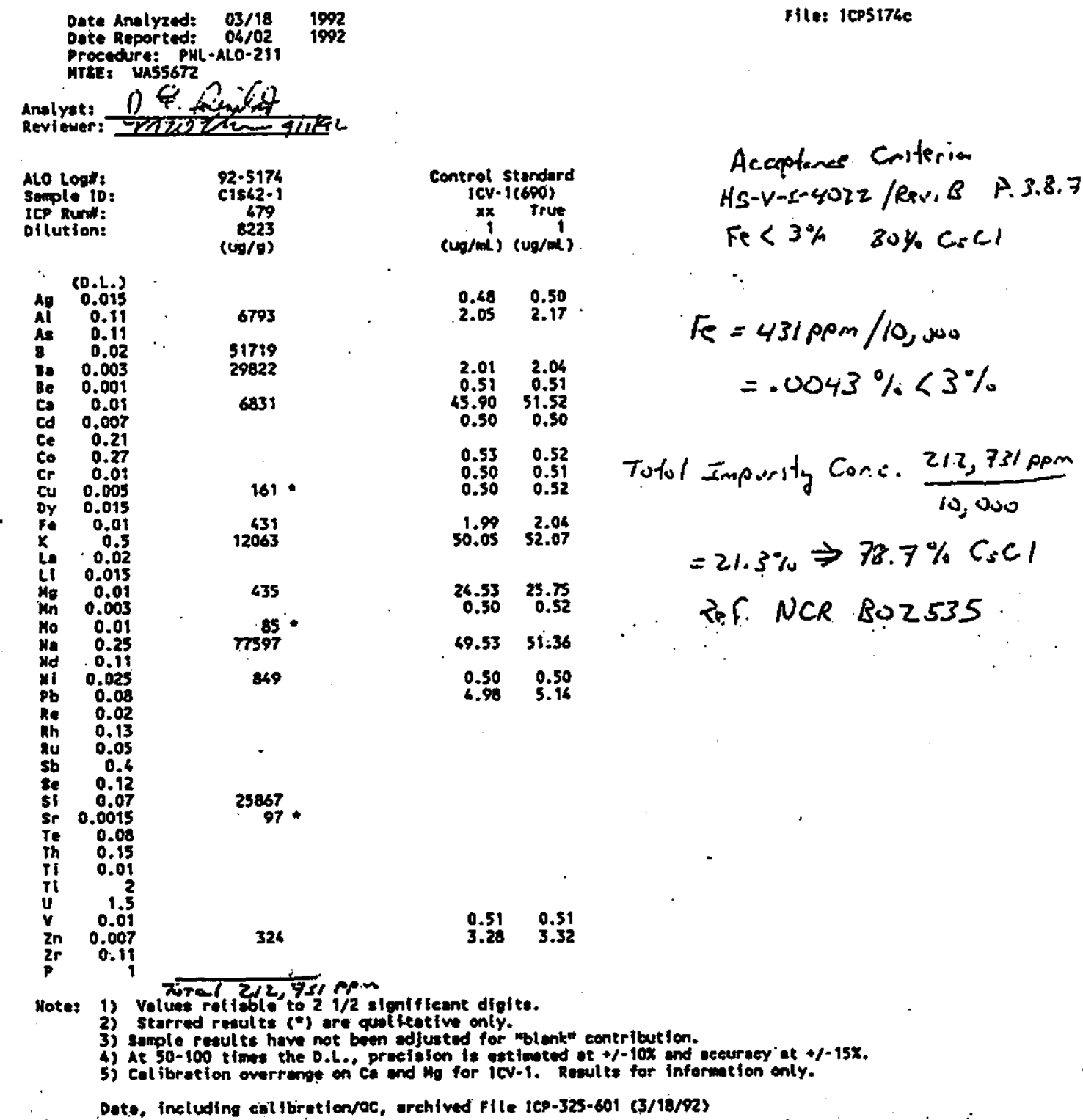


HNF-7342

Attachment 3

HNF-2928, Rev. 0 
HNF-7342

HNF-2928, Rev. 0

$5 / 14 / 98$

Cesium Capsule $\mathrm{C}-1550$

Outer Capsule ID: C-1550

Inner Capsule ID: $C-1434$

Production \#: 82-23

Calibration Date: $8 / 31 / 82$

Capsule Type: $\quad 3$

Double Capsule: YES

Capsule Age: 187

Gross Wt.: 8.762

Net Wt.: 2.692 .

Tare Wt.: 6.070

Melter Location: 4

Pour Temperature: $\quad 737$

Pour Date: $7 / 20 / 82$

Pool Cell Date: 9/01/82

PC Location: SHIP/CUT

Original $\mathrm{KCi}: 56.40$

Original Wattage: 270.70

Curies per gram: 15

Wattage Decayed: 188.88

Watt Decay Date: $5 / 01 / 98$

KCi Decayed: 39.35

KCi Decay Date: 5/01/98

Wattage per gram: 70

Gram Salt: 2.905

Remarks: SHIPPED TO PNL 2-28-90. CAPSULE CUT. LOOSE SALT

Remarks2:

QC Initials: CNH

OP Initials: RLJ

Destination: PNL-CUT

Date Shipped: $2 / 28 / 90$

Date Updated:

DSI Number: 
HNF-7342

HNF-2928, Rev. 0

$6 / 25 / 98$

C-1502

Page 1

Outer Capsule ID: C-1502

Inner Capsule ID: $\mathrm{C}-1438$

Production \#: 82-23

Calibration Date: $7 / 23 / 82$

Capsule Type:

3

Double Capsule: YES

Capsule Age: 191

Gross Wt.

Net $\mathrm{wt.}$ :

9

Taxe Wt.:

3

Melter Location: 5

Pour Temperature: $\quad 737$

Pour Date: $7 / 20 / 82$

Pool Cell Date: $7 / 27 / 82$

PC Location: SHIP/CU'

Original KCi: $\quad 56$

Original Wattage: 268

Curies per gram: 14

wattage Decayed: 186

Watt Decay Date: .7/01/98

KCi Decayed: 39

KCi Decay Date: 7/01/98

Wattage per gram:

Gram Salt: 3

Remarks: SHIPPED TO RSI, ATLANTA 01-22-86. SHIPPED TO ORNL 12-20-88

Remarks2: SHIPPED TO PNL. LEAKER. CUT OPBN 9-29-92

QC Initials: CNH

OP Initials: RUJ

Destination: RSI-A/OR/RNL/CUT

Date Shipped: $1 / 21 / 86$

Date Updated:

DSI Number: 


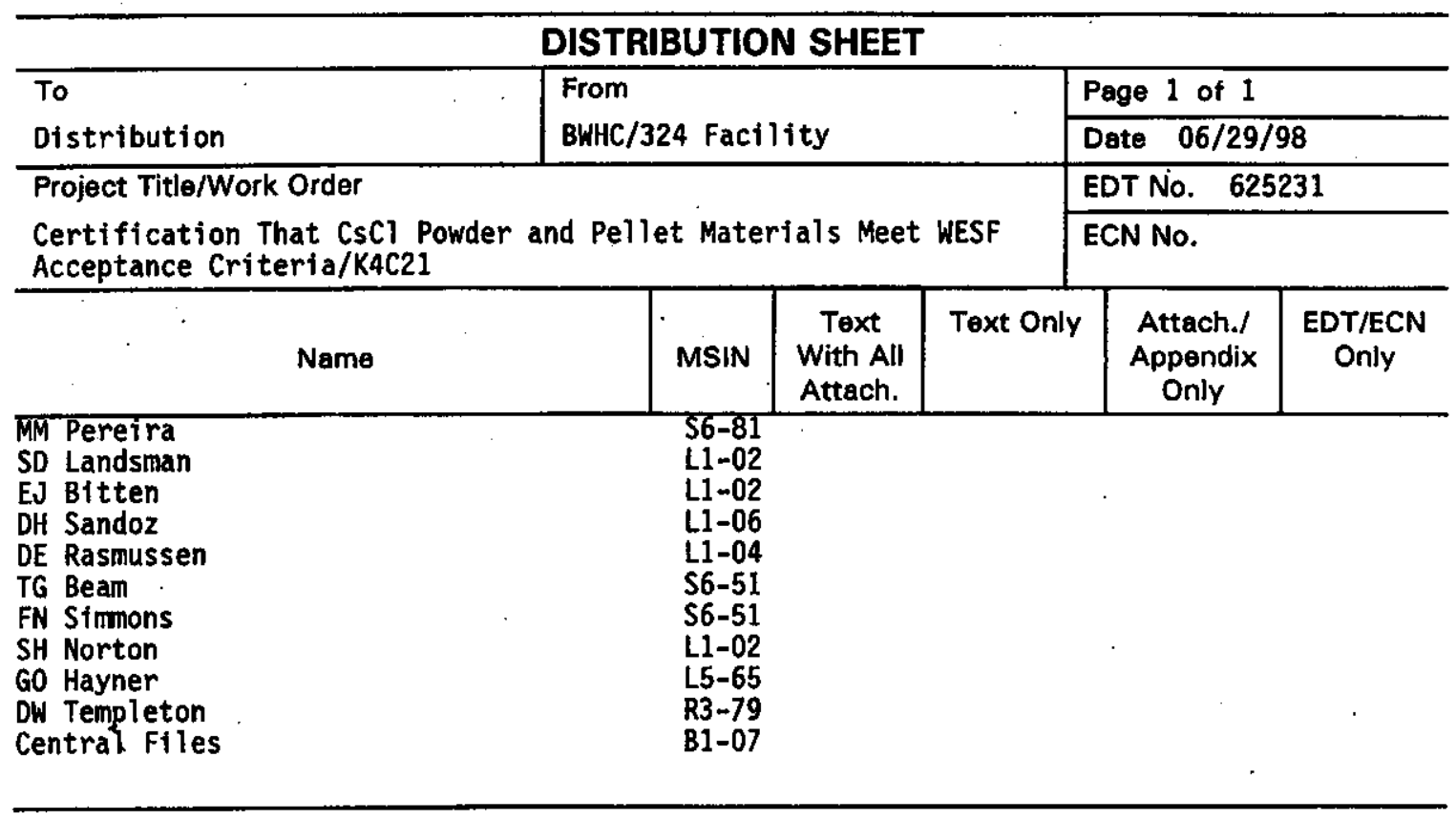


HNF-7342

This page intentionally left blank. 
HNF-7342

\section{ATTACHMENT 2}

CERTIFICATION THAT UNOPENED TYPE 4 CONTAINER OF CsCl IS ACCEPTABLE FOR PACKAGING DIRECTLY INTO TYPE W OVERPACK 
HNF-7342

This page intentionally left blank. 
HNF-7342

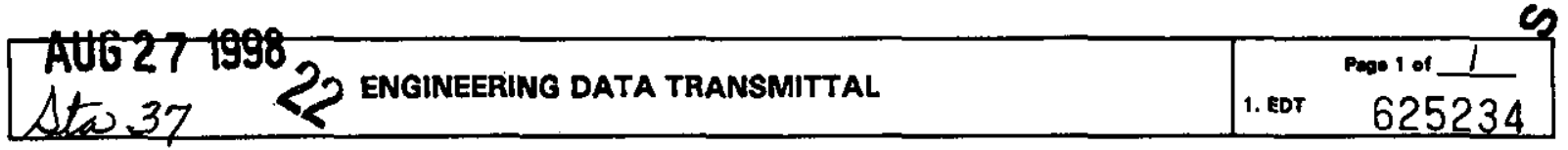

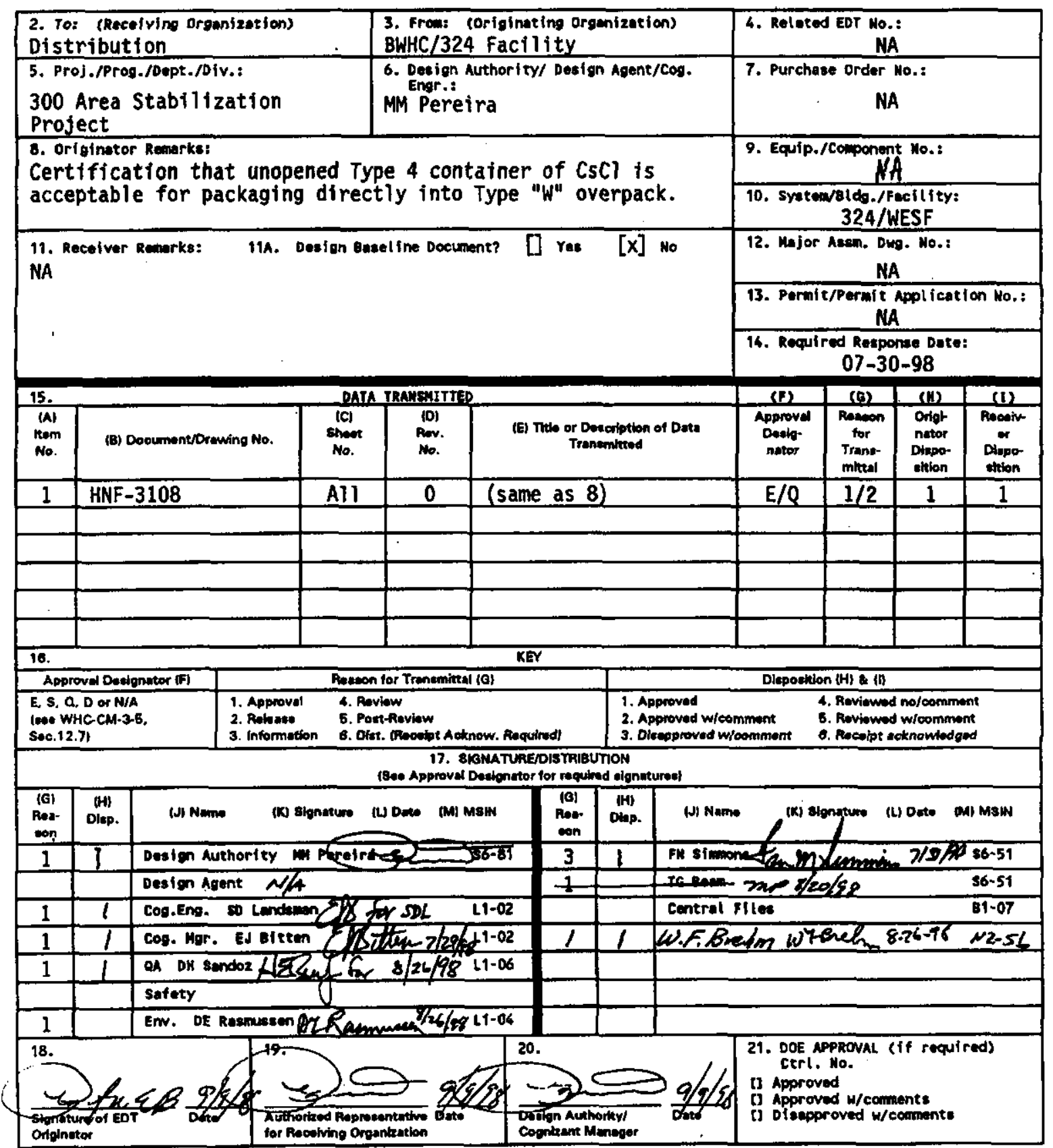

80-7400-172-2 (05/96) GEFO97 
HNF-3108, Rev. 0

\title{
304L Stainless Steel Resistance to Cesium Chloride
}

\author{
C. E. Graves \\ BWHC, Richland, WA 99352 \\ U.S. Department of Energy Contract DE-AC06-96RL13200 \\ EDT/ECN: 625234 \\ Org Code: 19350 \\ UC: 2000 \\ Charge Code: K4C21 \\ B\&R Code: EW7050000 \\ Total Pages: $6, y \cos _{z-27}-98$
}

Key Words: Cesium Chloride, Type 4 Canister, WESF Inner Capsule

Abstract: Certification that unopened Type 4 container of $\mathrm{CsCl}$ is acceptable for packaging directly into Type "W" overpack.

TRADEMURK DISCLAIKER. Reference herein to any specific commerclal procuct, process, or corvice by trade name, tredemark, menufacturer, or otheruise, does not neceasarily consti tute or inply its endorsement, recomendation, or favoring by the United states covernment or eny agency thereof or its contractors or subcontractors.

Printed in the United States of Americe. To obtain copies of this document, contact: Document control Services, P.0. Box 950, Mailstop H6-08, Richland un 99552, Phone (509) 372-2420; Fax (509) 376-4989.
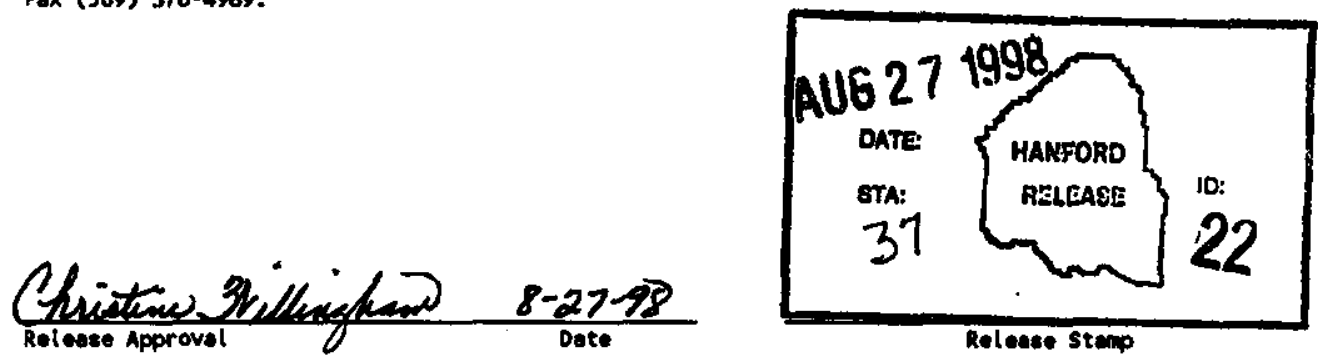

\section{Approved for Public Release}

A-6400-073 (01/97) GEF321 


\section{L STAINLESS STEEL RESISTANCE TO CESIUM CHLORIDE}

August 1998

Prepared by

C. E. Graves

Fluor Daniel Northwest

Richland, Washington 
HNF-7342

HNF-3108

Rev. 0

TABLE OF CONTENTS

Page

1.0 INTRODUCTION 1

$2.0316 \mathrm{~L}$ SS CORROSION RESISTANCE TO CsCl 1

$\begin{array}{ll}3.0 \text { DISCUSSION } & 2\end{array}$

4.0 CONCLUSIONS

5.0 REFERENCES 3

\section{ABBREVIATIONS / ACRONYMS}

\begin{tabular}{|c|c|}
\hline ALARA & As Low As Reasonably Achievable \\
\hline $\mathrm{Cd}$ & cadmium \\
\hline $\mathrm{Cl}$ & chlorine \\
\hline $\mathrm{Cr}$ & chromium \\
\hline $\mathrm{CsCl}$ & cesium chloride \\
\hline $\mathrm{Fe}$ & iron \\
\hline $\mathrm{H}$ & hydrogen \\
\hline in. & inch \\
\hline$\mu \mathrm{m}$ & micron $\left(10^{-6} \mathrm{~m}\right)$ \\
\hline Mn & manganese \\
\hline Mo & molybdenum \\
\hline $\mathrm{Ni}$ & nickel \\
\hline $\mathrm{O}$ & oxygen \\
\hline $\begin{array}{l}\text { ORNL } \\
\text { P }\end{array}$ & $\begin{array}{l}\text { Oak Ridge National Laboratory (Oak Ridge, Tennessee) } \\
\text { phosphorus }\end{array}$ \\
\hline PNNL & Pacific Northwest National Laboratory \\
\hline SEM & Scanning Electron Microscopy \\
\hline Si & silicon \\
\hline SS & stainless steel \\
\hline WESF & Waste Encapsulation and Storage Facility \\
\hline
\end{tabular}

2 
HNF-3108

Rev. 0

\section{L STAINLESS STEEL RESISTANCE TO CESIUM CHLORIDE}

\subsection{INTRODUCTION}

B\&W Hanford Company have two Oak Ridge National Laboratory (ORNL) Type 4 canisters filled with cesium chloride $(\mathrm{CsCl})$ originally produced at WESF (Waste Encapsulation and Storage Facility). These canisters are constructed of 304L stainless steel per drawing ORNL 970-294. Instead of removing the $\mathrm{CsCl}$ from the Type 4 canisters and repacking into an Inner Capsule, it is intended (for ALARA, schedule and cost purposes) that the Type 4 canisters be decontaminated (scrubbed) and placed [whole] inside a Type "W" overpack. The overpack is constructed from 316L stainless steel.

Several tests have been run by Pacific Northwest National Laboratory (PNNL) over the years documenting the corrosion compatibility of 316L SS with CsCl (Bryan 1989 and Fullam 1972). However, no information for 304L SS compatibility is readily available. This document estimates the corrosion resistance of $304 \mathrm{~L}$ stainless steel in a WESF CsCl environment as it compares with that of $316 \mathrm{~L}$ stainless steel.

\section{$2.0316 \mathrm{~L}$ SS CORROSION RESISTANCE TO CsCl}

Fullam (1972) extrapolated his short-term compatibility data to indicate the attack of $316 \mathrm{~L}$ SS by $\mathrm{CsCl}$ waste at $400^{\circ} \mathrm{C}\left(750^{\circ} \mathrm{F}\right)$ over a 600 year period should not exceed $635 \mu \mathrm{m}(0.025$ in.). Visual inspection of photomicrographs showed little evidence of intergranular penetration but some pitting and subsurface void formation was present. Carbide precipitation was evident near the sample surface and along grain boundaries. The extent of the carbide precipitation increased with time at temperature. ${ }^{\dagger}$

Bryan (1989) conducted long term (6 year) tests with WESF canisters to try to obtain more reliable estimates on the long-term corrosion resistance of $316 \mathrm{~L} \mathrm{SS}$ to $\mathrm{CsCl}$ at $450^{\circ} \mathrm{C}\left(840^{\circ} \mathrm{F}\right)$. His examination of photomicrographs also showed subsurface void formation and carbide precipitation (again, the number of precipitates increased with time at temperature).

The presence of carbide precipitates reduces the corrosion resistance of the stainless steel at the grain boundaries. 
HNF-3108

Rev. 0

Thermodynamic calculations by Bryan (1989) indicate that pure $\mathrm{CsCl}$ should not react with 316L SS at the test temperatures, however, certain impurities in the $\mathrm{CsCl}$ could react with the $316 \mathrm{~L}$ SS. Possible impurities that could react include the less stable chlorides, such as $\mathrm{FeCl}_{2}$, $\mathrm{NiCl}_{2}$, and $\mathrm{CdCl}_{2}$, and the less stable oxides such as $\mathrm{Fe}_{3} \mathrm{O}_{4}, \mathrm{NiO}$ and $\mathrm{H}_{2} \mathrm{O}$. In trying to identify the reactions, samples were analyzed by SEM (scanning electron microscopy). Bryan concludes that the only reaction that could be identified with any certainty was the leaching of $\mathrm{Mn}$ from the $316 \mathrm{~L}$ SS in the reaction zone.

If impurities in the $\mathrm{CsCl}$ are the principal cause of corrosion, the extent of reaction should be limited by the amount of impurities available to react with the 316L SS components. The corrosion rate would initially be high and then decrease with time as the impurities are consumed. The rate controlling step for each reaction is likely to be the diffusion of the impurity reactant from the bulk CsCl to the metal/CsCl interface (Bryan 1989). If a liquid phase is present, it could accelerate this diffusion.

Bryan tabulated the effect of impurities on the phase transition temperature and melting point of $\mathrm{CsCl}$ (1989, pg A.17). The impurity with the greatest effect is iron. For a $\mathrm{CsCl}+3 \% \mathrm{FeCl}_{3}$ system the minimum melting point is $270^{\circ} \mathrm{C}\left(520^{\circ} \mathrm{F}\right)$; melting began before a phase transition temperature could be detected. This falls well below the test temperature, thus a liquid phase would be present.

When pure molten $\mathrm{CsCl}$ is poured into a 316L SS capsule and allowed to solidify, the solid mass does not adhere to the wall (void spaces are formed as the mixture cools and collapses). Bryan (1989) hypothesizes that impurities cause some of the $\mathrm{CsCl}$ to adhere to the capsule wall. Thus, corrosion in areas where there is no $\mathrm{CsCl} /$ steel contact should be much less than in contact areas. If samples were [inadvertently] taken in areas of no contact, this theory could help to explain some of the data scatter in previous studies.

\subsection{DISCUSSION}

304L and 316L SS are both austenitic stainless steels with similar compositions (see Table 1). The lower carbon values (versus 304 and 316) improve corrosion resistance in welded structures (ASM 1990). The addition of molybdenum in 316L SS increases the steel's resistance to the initiation of pitting and crevice corrosion (ASM 1990). Both of these alloys are used extensively in the nuclear industry.

Table 1: Stainless Steel Compositions (ASM 1990,pg 843)

\begin{tabular}{|c|c|c|c|c|c|c|c|c|}
\hline \multirow{2}{*}{ Type } & \multicolumn{7}{|c|}{ Composition, wt.\% (Remainder is Fe) } \\
\cline { 2 - 9 } & $\mathbf{C}$ & Mn & Si & Cr & Ni & P & S & Mo \\
\hline 304L & 0.03 & 2.00 & 1.00 & $18-20$ & $8-12$ & 0.045 & 0.03 & $\ldots$ \\
\hline
\end{tabular}


HNF-3108

Rev. 0

\begin{tabular}{|l|l|l|l|l|l|l|l|l|}
\hline $316 \mathrm{~L}$ & 0.03 & 2.00 & 1.00 & $16-18$ & $10-14$ & 0.045 & 0.03 & $2.00-3.00$ \\
\hline
\end{tabular}

With the great similarity in composition between the $304 \mathrm{~L}$ and 316L SS (equal amounts of $\mathrm{Mn}$ and $\mathrm{Si}$, near equal amounts of $\mathrm{Cr}$ and $\mathrm{Ni}$ ), the potential corrosion reactions with the $\mathrm{CsCl}$ would also be similar (leaching of manganese in the reaction area). As subsurface void formation and carbide precipitation are the predominate corrosion features observed, the addition of molybdenum to the 316L [to reduce pitting and crevice corrosion] does not seem to provide an extra advantage to corrosion resistance.

During its stay at $\mathrm{ORNL}$, the $\mathrm{CsCl}$ was water-washed which lowered the impurity levels (Landsman 1998), thus lowering the amount of available corrosion reactants. The lowering of iron content by washing (to $<0.005 \%$ ) would also minimize the potential for any liquid phase to form and decrease impurity diffusion to the surface. Water storage of this WESF canister would greatly reduce the system ( $\mathrm{CsCl} /$ steel) temperature, which in turn would further lower corrosion rates.

Corrosion on the exterior of the Type 4 canister due to any remaining $\mathrm{CsCl}$ after decontamination would be minimal, as any impurity would be quickly consumed. Lastly, as no water or moisture is expected between the Type 4 canister and the WESF overpack, any possible galvanic corrosion between the $304 \mathrm{~L}$ and $316 \mathrm{~L} \mathrm{SS}$ is avoided. As these two alloys are only slightly separated on the galvanic series (ASM 1990, pg 557), galvanic corrosion would be unlikely even with water present.

\subsection{CONCLUSIONS}

With much lower impurity levels in the water-washed ORNL CsCl and a similar steel composition, the 304L stainless steel is expected to exhibit equal to or better corrosion resistance than the 316L stainless steel in this application. Thus, packing of the Type 4 canisters within the WESF overpack is judged acceptable.

\subsection{REFERENCES}

ASM, 1990, "Stainless Steels" in Metals Handbook, Volume 1 - Properties and Selection: Irons, Steels, and High-Performance Alloys, 10th Edition, American Society for Metals, Metals Park, Ohio.

Bryan, G. H., 1989, Cesium Chloride Compatibllity Testing Programm-Final Report, PNL-7133, Pacific Northwest Laboratory, Richland, Washington.

Fullam, H. T., 1972, Compatibility of Cesium Chloride and Strontium Fluoride With Containment Materials, BNWL-1673, Pacific Northwest Laboratory, Richland, Washington. 
HNF-3108

Rev. 0

Landsman, S. D., 1998, Certification That CsCl Powder and Pellet Materials Meet WESF Acceptance Criteria, HNF-2928, Rev. 0, B\&W Hanford Company, Richland, Washington.

ORNL, "Powder Shipping Cans - Type 4 (SK-365-B)", ORNL Dwg \#970-294, Oak Ridge National Laboratory, Oak Ridge, Tennessee. 
HNF-7342

\section{DISTRIBUTION}

U.S. Department of Energy, Richland Operations Office

E. M. Mattlin

A5-15

S. K. Moy

$\mathrm{H} 0-12$

G. L. Sinton

H0-12

Fluor Hanford

C. K. Girres

T3-01

B. Oldfield

S6-81

F. M. Simmons (5)

S6-81

Lockheed Martin Services, Inc.

Central Files

B1-07

DPC

H6-08 
HNF-7342

This page intentionally left blank. 